XVI CONGRESO LATINOAMERICANO DE PATOLOGÍA DE LA CONSTRUCCÍN
XVIII DE CONTROL DE CALIDAD EN LA CONSTRUCCIÓN

\title{
Evaluation of the Performance of Rice Husk-Ash in Mitigating DEF in Concrete.
}

\author{
G. Amantino ${ }^{1 *}$, N. Hasparyk ${ }^{2 *}$, F. Tiecher ${ }^{3 *}$ \\ *Amantino: amantino.eng@gmail.com \\ *Hasparyk: nicolepha@gmail.com \\ *Tiecher: Francieli.bonsembiante@imed.edu.br \\ ${ }^{1}$ Master student in Civil Engineering of Faculdade Meridional - IMED, Passo Fundo, Brazil \\ ${ }^{2} \mathrm{PhD}$, Researcher of Departamento de Segurança de Barragens e Tecnologia, ELETROBRAS Furnas, Goiânia, \\ Brazil \\ ${ }^{3} \mathrm{PhD}$, Professor in Civil Engineering of Faculdade Meridional - IMED, Passo Fundo, Brazil
}

\begin{abstract}
This paper aims to present the behavior of concrete containing rice husk-ash (RHA) that were undergone a thermal curing. A particular test method was used to promote an initial thermal curing up to $85^{\circ} \mathrm{C}$ to trigger $\mathrm{DEF}$, followed by a specific exposure condition $\left(\right.$ at $\left.38^{\circ} \mathrm{C}\right)$. Expansion measurements and microstructural analyses were performed to evaluate the level of attack and the integrity of concretes with and without rice husk-ash (RHA). Mechanical properties were assessed in order to monitor damage evolution of generated expansions from DEF over time and up to six months. Concrete tests have indicated that the RHA tested was able to reduce DEF expansions, nonetheless, it was not enough to a complete mitigation and avoid DEF and damages.
\end{abstract}

Keywords: DEF; Expansion; Concrete; Rice husk-ash; Mitigation

\section{RESUMO}


Este artigo tem o objetivo de apresentar o comportamento de concretos contendo cinza de casca de arroz (CCA) que foram submetidos à cura térmica. Um específico método de ensaio foi utilizado envolvendon uma cura térmica inicial com temperatura de pico igual a $85^{\circ} \mathrm{C}$ para induzir a $\mathrm{DEF}$, seguido por uma condição de exposição por imersão em água, a $38^{\circ} \mathrm{C}$. Medidas de expansão e análises microestruturais foram realizadas para avaliar o nível de ataque e a integridade dos concretos com e sem cinza da casca de arroz (CCA). Propriedades mecânicas também foram avaliadas com o objetivo de monitorar a evolução dos danos das expansões geradas pela DEF ao longo do tempo, e até seis meses. Os resultados dos ensaios com os concretos indicaram que a CCA testada foi capaz de reduzir as expansões da DEF, entretanto, não foi suficiente para uma mitigação completa e evitar os danos ocasionados pela DEF.

Keywords: DEF; Expansão; Concreto; Cinza da casca de arroz; Mitigação

\section{RESUMEN}

Este artículo tiene como objetivo presentar el comportamiento de hormigones que contienen cenizas de cascarilla de arroz (CCA) que fueron sometidos a un curado térmico. Se utilizó un método de prueba particular para promover un curado térmico inicial de hasta $85^{\circ} \mathrm{C}$ para desencadenar DEF, seguido de una condición de exposición específica por inmersión en agua $\left(38^{\circ} \mathrm{C}\right)$. Se realizaron mediciones de expansión y análisis microestructurales para evaluar el nivel de ataque y la integridad de los hormigones con y sin cascarilla-ceniza de arroz (CCA). También se evaluaron las propiedades mecánicas para monitorear la evolución del daño de las expansiones generadas por DEF a lo largo del tiempo y hasta seis meses. Pruebas concretas han indicado que CCA pudo reducir las expansiones de DEF, sin embargo, no fue suficiente para una mitigación completa y evitar DEF y daños.

Keywords: DEF; Expansión; Hormigón; Ceniza de cáscara de arroz; Mitigación

\section{INTRODUCTION}


Durability studies focused on concrete structures is very wide, embracing test procedures and practical recommendations to avoid or mitigate some negative occurrences. Several internal and external factors can act isolated or even with a joint interaction leading to damages. Delayed ettringite formation (DEF) is an example of expansive reaction that can lead concrete to severe deterioration. The occurrence of this secondary ettringite inside hardened concrete involves sulfates, aluminates and high levels of temperatures (above $65^{\circ} \mathrm{C}$ ) at the first hours of cement hydration (Taylor, 1997; IFSTTAR, 2018). This delayed ettringite crystalizes in the presence of moisture (above 90\%) and after concrete cools (Godart, 2017). Rise temperature can occur in two ways: due to the exothermic reactions from cement hydration, and especially in mass concrete or due to improper temperature of thermal curing, mainly in pre-cast elements (LCPC, 2009). Several concrete structures have been suffering from DEF, according to some publications around the world (Seignol et al., 2012; Bauer et al., 2006, Hasparyk and Kuperman, 2019).

The main physical manifestations of DEF are related to cracking formation from expansions in the cement matrix that compromise concrete integrity, and specially modulus of elasticity (Jeong et al., 2017; Giannini et al., 2018; Schovanz, 2019). DEF occurs earlier and more aggressive when compared to other expansive chemical reactions, such as AAR, for example. Schovanz et al. (2021) have presented concrete damaged with DEF with loss of about $65 \%$ for compressive strength in laboratory studies. There is no practical recommendation to mitigate this problem once a concrete deteriorated. If there is a risk of concrete to suffer from high temperatures, the indication is the use of cooling procedures to reduce the level below $60^{\circ} \mathrm{C}$ (Hasparyk et al., 2020). In the case of further prevention procedures, the use solely of mineral admixtures do not guarantee a complete mitigative condition. Certainly, the use of pozzolanic admixtures promotes a pore refinement and also a reduction in the permeability (Mehta and Monteiro, 2014). The studies with fly-ash presented by Amine et al. (2017) and Asamoto et al. (2017) indicate the potential of this pozzolan to mitigate DEF, at contents of $15 \%$ and 25\%. On the other hand, Schovanz (2019) and Bronholo (2020) did not achieve the same efficiency with the content of about $26 \%$ once delayed ettringite was seen in the microstructure of concretes, even though with no expressive negative impact in the physical and mechanical properties until 270 and 365 days, respectively. Ramlocham et al. (2003) had also verified the performance of mineral admixtures in DEF studies and had concluded that silica fume was not proper to mitigate DEF at $8 \%$, but the slag at $25 \%$ performed successfully for this purpose. In relation to rice husk-ash (RHA) and DEF, it was not found studies with this purpose. Furnas/Aneel and the R\&D Project entitled "Metodologias e infraestrutura tecnológica para aperfeiçoamento das avaliações de confiabilidade e otimização de empreendimentos de energia", enable the development of experimental program in this subject contemplating RHA in mortars (Oliveira et al., 2020) and concretes (presented partially in this paper).

It is also important to point out that RHA can prevent the expansive reaction of AAR type, depending on its crystallinity and content (Hasparyk, 1999; Zerbino et al., 2012), as well as for chloride attack, carbonation and also external sulfate attacks (Fournier and Bérubé, 2000; Givi et al., 2010; Ramasamy, 2012).

This pozzolan admixture is available in several localities (Global production of about 500 millions of tons per year - Foreign Agricultural Service, 2019). The south of Brazil is responsible for 11 millions of ton per year (Irga, 2021). In addition, rice husk is a waste that corresponds to $20 \%$ in weight of the rice produced (Lopes et al., 2017). The disposal of this waste is a problem and the husk have been used as combustible material in several industries producing the ash from this husk, that is highly attractive due to its active characteristics as pozzolan (Sensale, 2010; Das et al., 2020). 
According to Gartner and Hirao (2015), the energy consumed in the production of clinker can reduce $\mathrm{CO}_{2}$ of about $5 \%$ by the use of pozzolanic alternative materials, such as RHA and contribute to avoid the global warming.

The main purpose of this study was to evaluate the behavior of concretes with and without RHA induced to DEF.

\section{EXPERIMENTAL STUDY}

\subsection{Materials, concrete mix and investigation program}

The materials used are presented below:

- Brazilian cement: ASTM type III portland cement.

- Rice husk-ash (RHA).

- Coarse and fine aggregates from granitic rocks being ASR non-reactive ones, according to ASTM C1260; NBR 15577-4: 2018).

- Polyfunctional chemical admixture composed of lignosulfonate and polycarboxylate.

The cement used is a High Early Strength Cement (HE). The oxide percent compositions of portland cement used are $\mathrm{CaO}: 55.38 ; \mathrm{SiO}_{2}: 18.39 ; \mathrm{Fe}_{2} \mathrm{O}_{3}: 4.35 ; \mathrm{Al}_{2} \mathrm{O}_{3}:$ 5.38; $\mathrm{TiO}_{2}: 0.47$; $\mathrm{Na}_{2} \mathrm{O}: 0.35 ; \mathrm{K}_{2} \mathrm{O}: 1.02 ;$ and $\mathrm{SO}_{3}: 1.88$. Data from RHA are: $\mathrm{CaO}: 0.75 ; \mathrm{SiO}_{2}: 86.51 ; \mathrm{Fe}_{2} \mathrm{O}_{3}: 0.42$; $\mathrm{Al}_{2} \mathrm{O}_{3}: 0.38 ; \mathrm{TiO}_{2}: 0.00 ; \mathrm{Na}_{2} \mathrm{O}: 0.00 ; \mathrm{K}_{2} \mathrm{O}: 1.17 ; \mathrm{P}_{2} \mathrm{O}_{5}: 1.11$; and $\mathrm{SO}_{3}: 0.00$. Loss on ignition of cement and RHA is equal to $3.83 \%$ and 9.81, respectively. RHA used in the experiments is a mineral admixture obtained from the use of rice husk as a fuel material in the Brazilian industry and its crystallographic features are presented in the Fig. 1, indicating some peaks of cristobalite and quartz. Cristobalite represents a polymorph phase of silica formed at very high-temperatures.

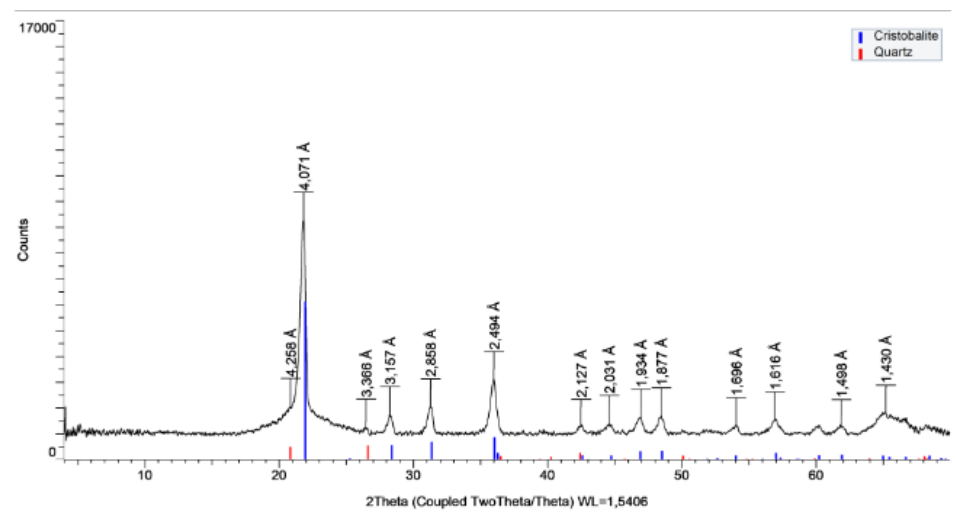

Figure 1. X Ray diffraction of RHA.

Coarse aggregate was used at $19 \mathrm{~mm}$ of maximum size with a fineness modulus of 6.82; fine aggregate fineness modulus was 3.11 , both, from granitic rocks. The following cement:aggregate ratio was adopted in the mixture: $1: 5.31$. The concrete mix scontains a cement content of $350 \mathrm{~kg} / \mathrm{m}^{3}$ and a water/cement of 0.58 . A reference concrete was cast with no admixture. A second mix was produced by weight replacement of cement with RHA $(8 \%)$. The concrete mix tested is widely applied in foundation elements of buildings in Brazil far form coast. The DEF process studied and presented is related to an internal sulfate attack (ISA) from cement due to thermal curing as well as from high hydration heat, thus, not external sulphate (ESA). Concrete prisms ( $75 \times 75 \times 285 \mathrm{~mm})$ specimens and also cylindric ones $(100 \times 200 \mathrm{~mm})$ were cast for expansion and mechanical tests, respectively, over time. At 28 and 180 days, some samples were collected from selected fragments of concrete specimens tested in order to be analyzed under scanning electron microscopy (by SE - 
secondary electrons) and energy dispersive X-ray spectrometry (SEM/EDS). Those observations were performed in fracture surfaces, after gold sputtering. The procedure adopted for the dimensional monitoring was the same described for the CPT, in the study of ASR (according to ASTM C-1293) for concrete prisms, by readings through studs positioned in the specimen edges. For mechanical tests, axial compressive strength and modulus of elasticity, Brazilian standards were applied at the ages of 7, 28, 90 and 180 days (ABNT NBR 5739; ABNT NBR 8522).

\subsection{Curing and storage conditions}

For DEF evaluation over time, cast specimens were undergone a specific condition that favored DEF occurrence. It was applied a thermal curing based on Hasparyk et al. (2020) and Schovanz et al. (2021), by using a temperature high exposition $\left(85^{\circ} \mathrm{C}\right)$ for 12 hours, after mixing. In the sequence, specimens were maintained in a chamber by water immersion at $38^{\circ} \mathrm{C}$ during six months. Over time and at established periods, specimens were removed from chamber to perform the tests indicated in 2.1 .

\section{RESULTS}

\subsection{Expansions}

Figure 2 shows that concrete prisms with no RHA began to produce expansion shortly after one month and, immediately after two months, individual expansions overpassed $0.04 \%$. After six months, the level of DEF expansions was very expressive, with an average of about $0.30 \%$. In contrast, concrete containing RHA featured a little different, with expansions of $0.23 \%$ at six months. This behavior has indicated some potential of this mineral admixture in mitigating DEF expansions. By calculation the percentage of reduction in expansions of RHA concrete in relation to the reference concrete, with no admixture (in the presence of the same cement), RHA concrete was able to mitigate $25 \%$ the expansions at one month, with an increase of its performance up to 63 days, by achieving a reduction of the order of 55\%. However, the same behavior after this period was not observed in relation to the RHA mitigation due to the continuous internal development of DEF over time, according to the produced expansions (Fig. 2) and microscopic analyses (Fig. 8), with an important increase of ettringite crystals. At six months, the RHA concrete mitigation was only about $25 \%$, on average, in relation to the reference concrete (Fig. 2).

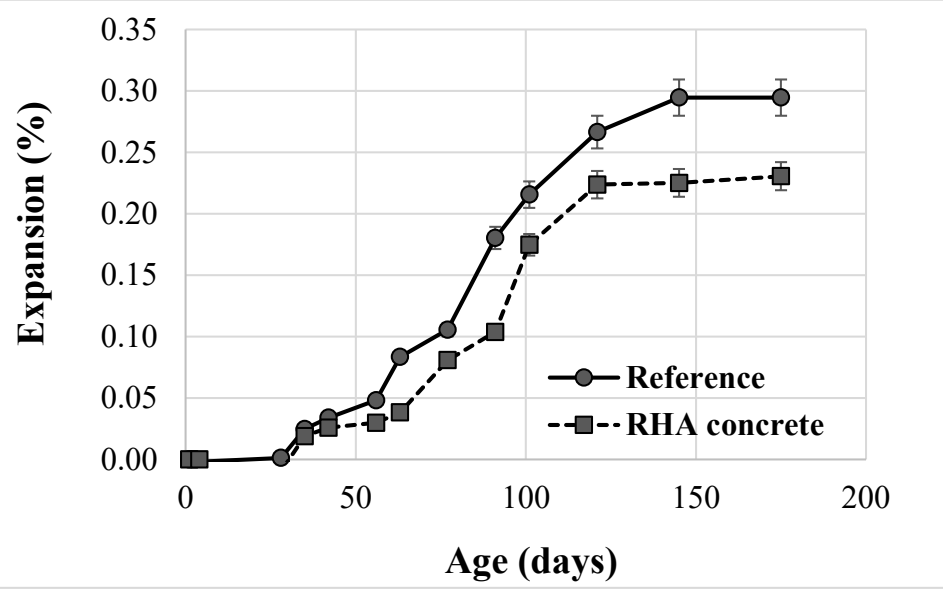

Figure 2. Expansive behavior of reference concrete. 
For DEF, there are no national standards for prevention. Some researchers tested a few mineral admixtures. Fly-ash, silica fume and slag, for example, show some potential to reduce risks of DEF, depending on the content used, according to Silva et al. (2010), Bauer et al. (2006), Schovanz et al. (2021). For ashes from rice, researches related to DEF were not detected.

\subsection{Mechanical properties}

Compressive and tensile strength were evaluated with specimens of concretes after thermal cycle (2.2) in order to monitor the influence of RHA over time.

Average data from compressive strength up to 180 days are presented in the Figure 3 . From 7 to 28 days, there is an increase in this property and more expressive for RHA concrete, from then on, significant decreases occurred up to 180 days for both concretes. The compressive strength of reference concrete at 180 days represents just about $50 \%$ of the one at 28 days; in the case of RHA concrete, this relation represents $60 \%$.

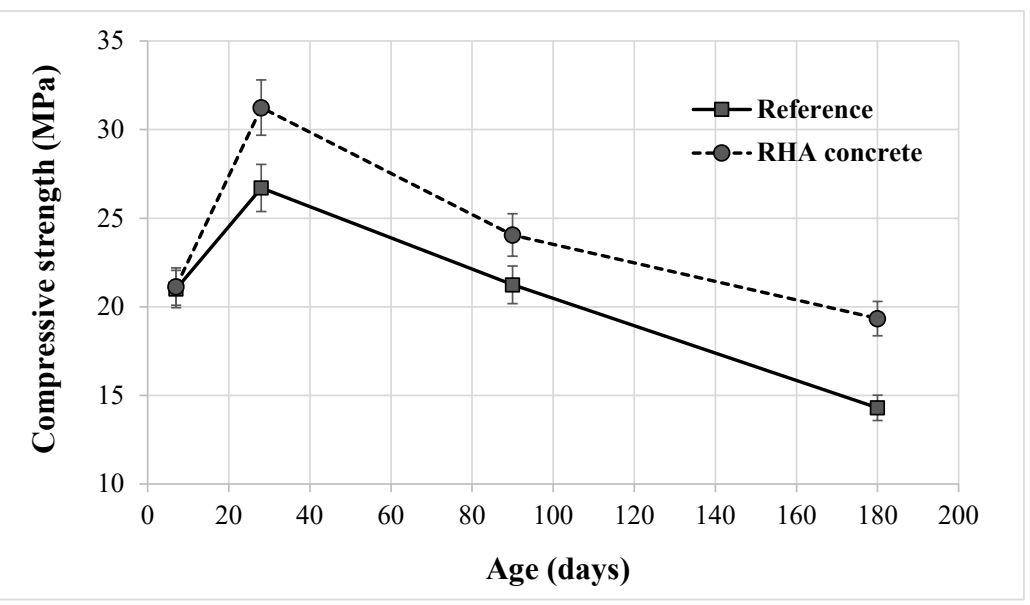

Figure 3. Compressive strength evolution over time.

Some studies have already been presenting compressive strength as very sensitive to DEF at early ages in comparison to other expansive reactions in concrete (Melo, 2010; Sanchez et al., 2018). DEF expansions are much more intense, according to Giannini et al. (2018). As expected, modulus (Figure 4) had also suffered negative influence for both concretes from 28 days, though losses were smaller compared to compressive strength for RHA concrete (about 20\% from 180 to 28 days), indicating less cracking, according also to Figure 2. In contrast, at 180 days the modulus of elasticity from reference concrete represents $60 \%$ when compared to the one at 28 days, with a similar behavior to the compressive strength. This behavior is in consonance to the one observed by Schovanz (2019) in the presence of other pozzolanic material in mitigating DEF. 


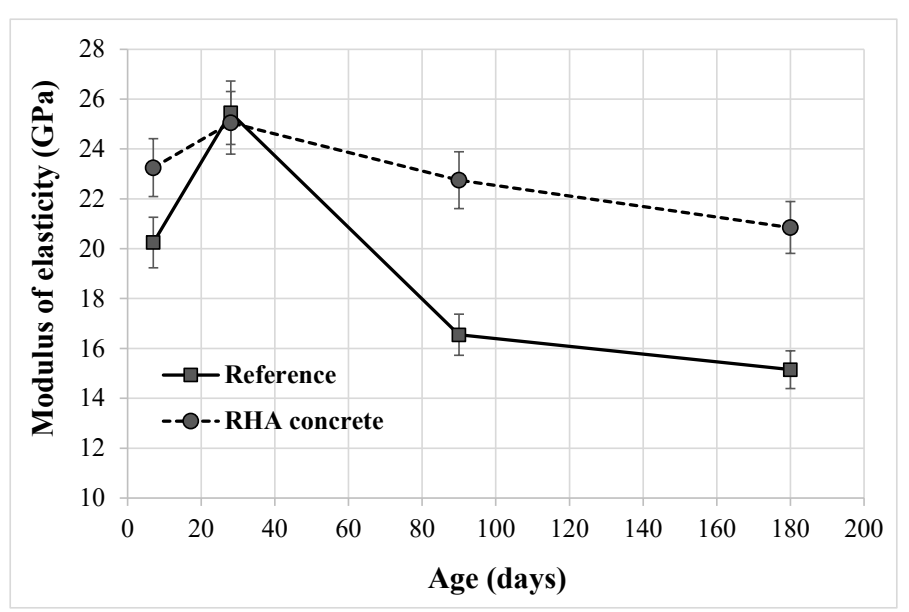

Figure 4. Modulus of elasticity evolution over time.

\subsection{Visual monitoring}

The surface of concrete prisms was monitored in order to detect some signs of DEF. It was remarkable the important difference between concrete with and without RHA. Concrete without RHA featured clear signs of ettringite formation over time, with white deposits in the voids and microcracking. In contrast, concrete with RHA did not promote cracking up to the evaluated age of six months, but few whitish formations could be observed (Figure 5).

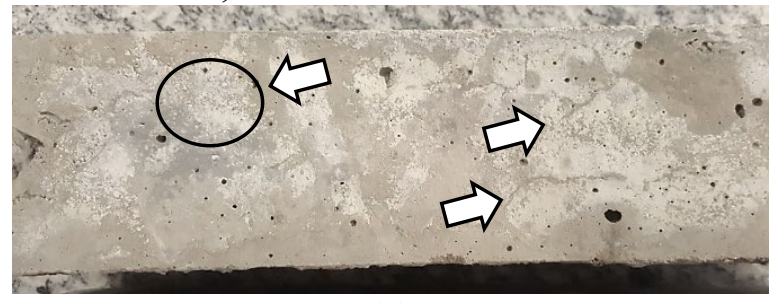

(a)

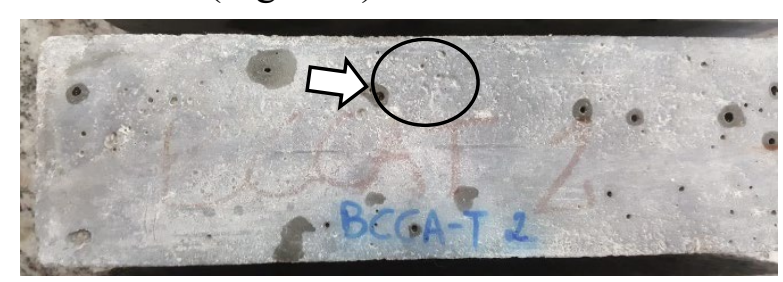

(b)

Figure 5. Surface of reference concrete (a) and RHA concrete (b), after 180 days.

White formations were also reported in DEF studies, such as Oliveira et al. (2020) with a similar experimental program involving DEF in mortars. In the SEM analyses the researches ascribed the white formations to the delayed ettringite. Schovanz et al. (2021) studied the behavior of concretes with fly-ash exposed to DEF up to 252 days and did not noticed external symptoms of ettringite, as well. However, evidences of secondary ettringite were observed through microstructural analyses of the internal portions of concretes suggesting further investigations for a longer period of time to certify their performance and expansions mitigative effect.

\subsection{Microstructural analyses}

Based on the microstructural analysis by means of SEM/EDS, it was observed an important formation of crystals of ettringite over time, from one to six months. It represents the inhibition of primary ettringite at the first ages and over time, with high moisture, sulfate ions could be available to produce deleterious secondary ettringite. Furthermore, the presence of ettringite formation was verified for both concretes (with and without rice husk-ash), even though reference concrete, without this pozzolan, featured a major incidence of those neoformations by SEM. Figure 6 shows micrographs registered during SEM analyses at 28 days. Concretes featured with normal 
characteristics, with empty voids and integrity of the cement matrix. On the other hand, at six months the integrity of both concretes was shattered, with several voids filled by acicular crystals and also massive formations of ettringite. Furthermore, radial cracks (Figure 7 (a) and Figure 8 (a)) and also detachments in the interfacial transition zone were observed, accompanied by ettringite crystals (Figure 7 (b) and Figure 8 (b)). Some similar characteristics were reported by Schovanz et al. (2021) in concretes cast with a similar cement, with no admixture. Other researchers had detected DEF in concretes containing pozzolans by microscopic analyses (Leklou et al., 2017).
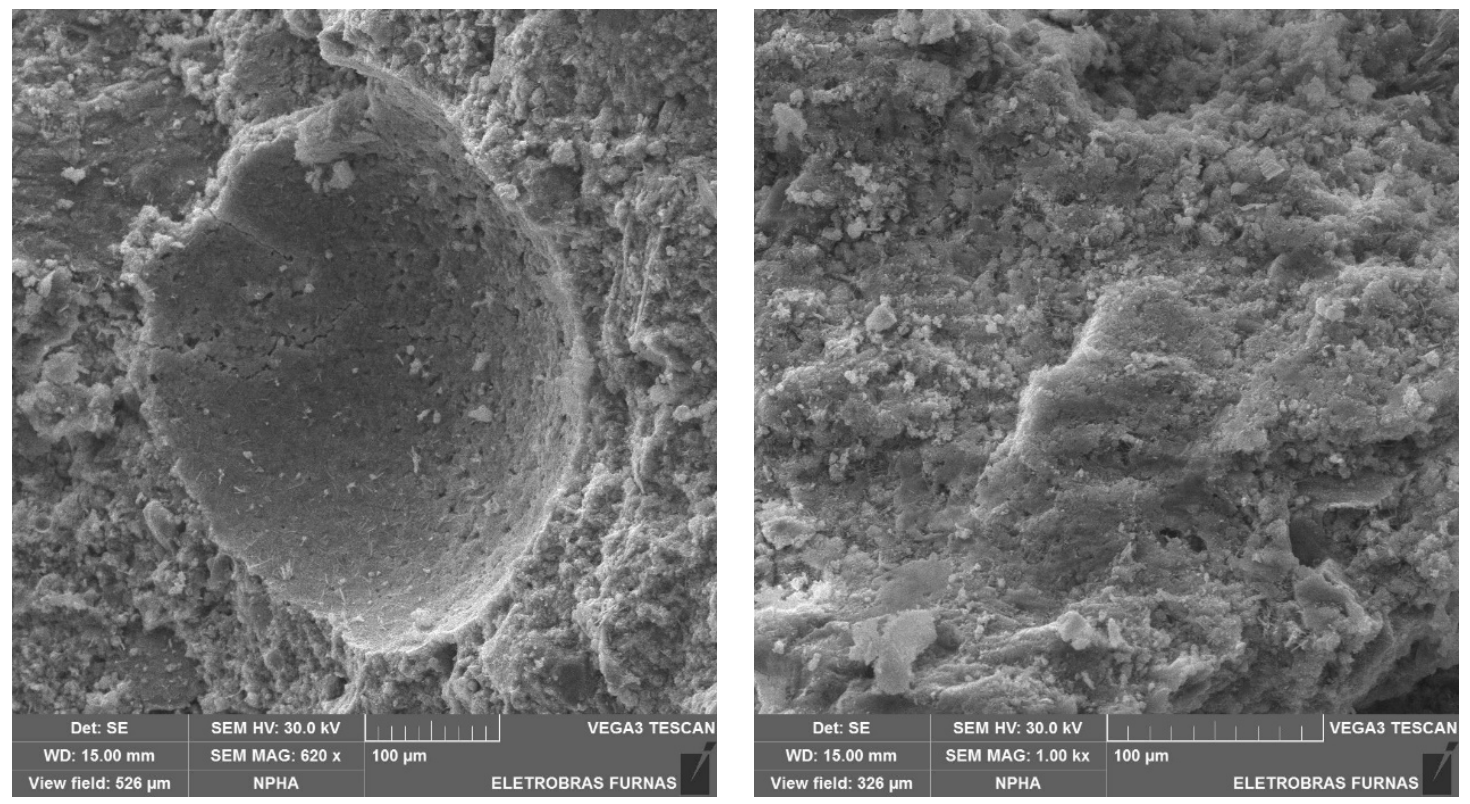

(a)
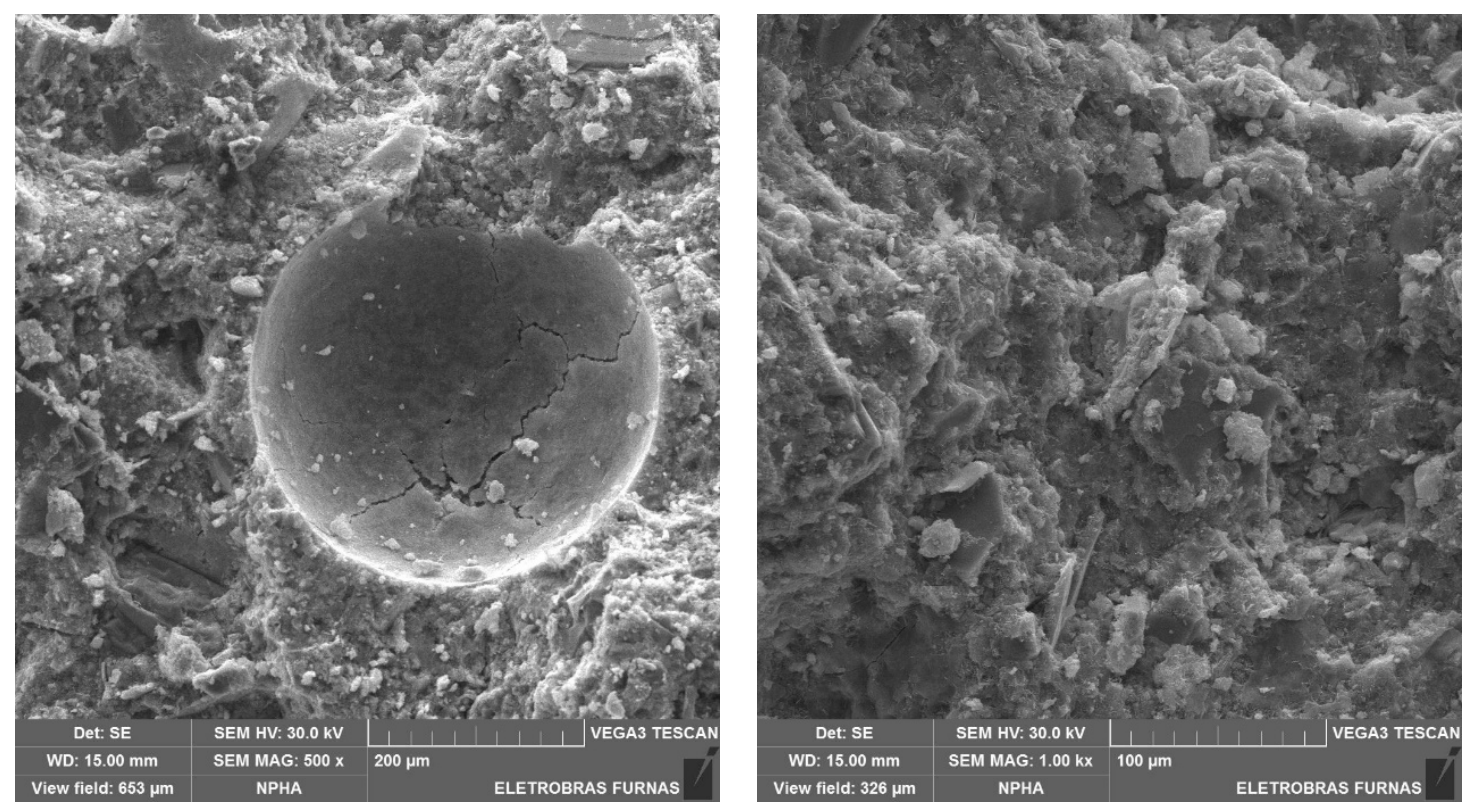

(b)

Figure 6. SEM micrography on day 28 of the assay. (a) reference concrete; (b) RHA concrete. 


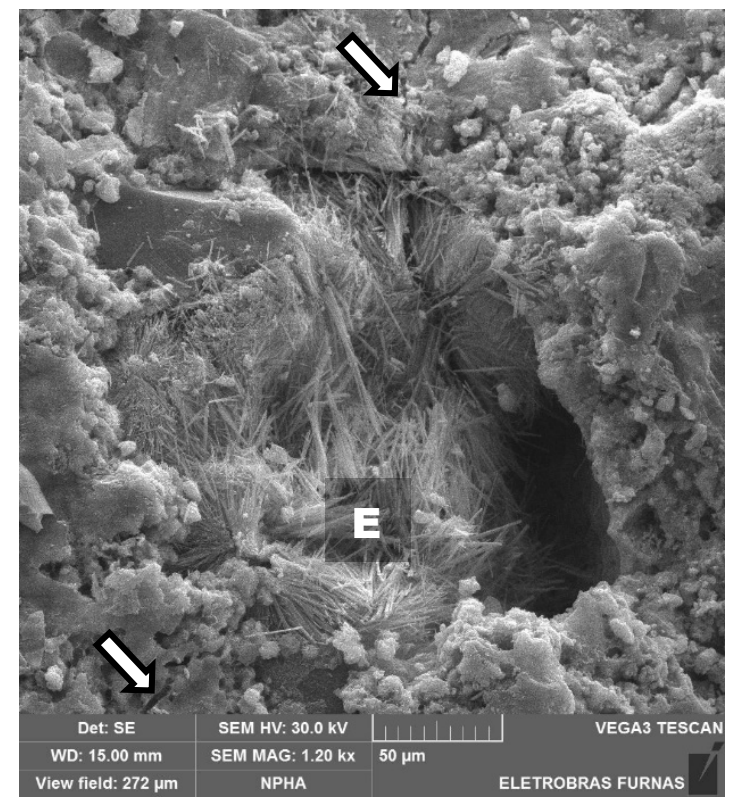

(a)

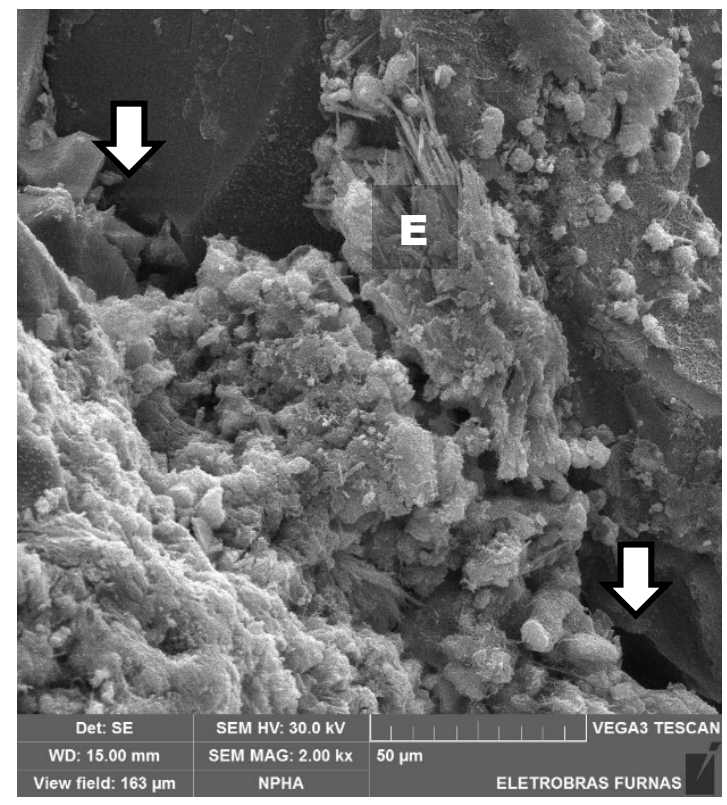

(b)

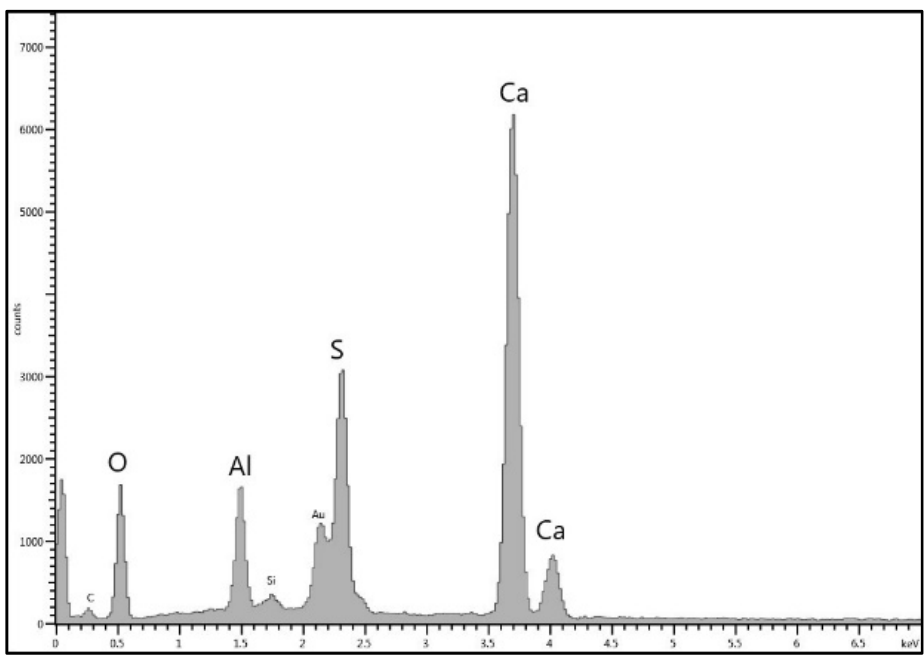

(c)

Figure 7. SEM micrography and EDS on day 180 of the assay for reference concrete. 


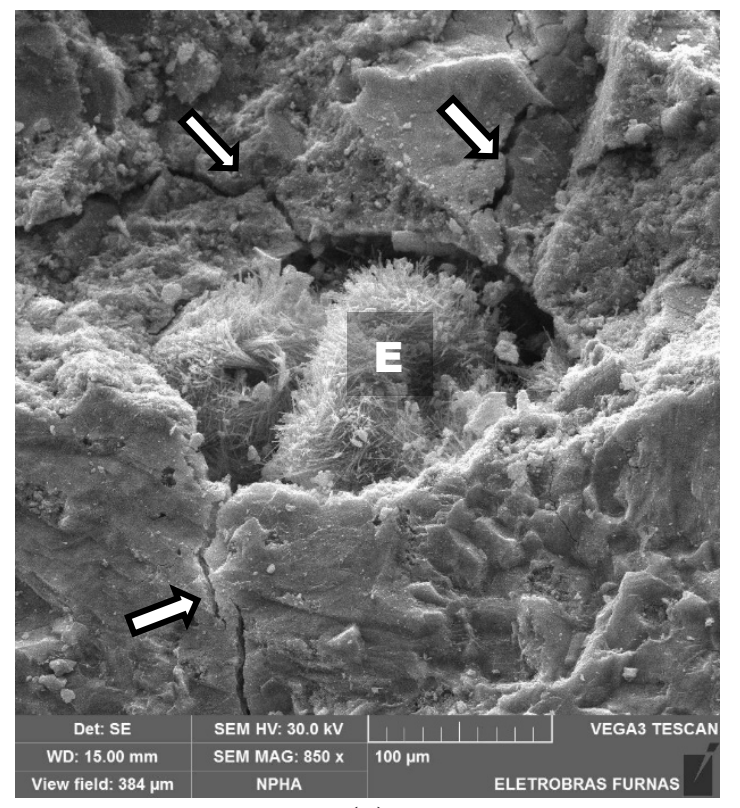

(a)

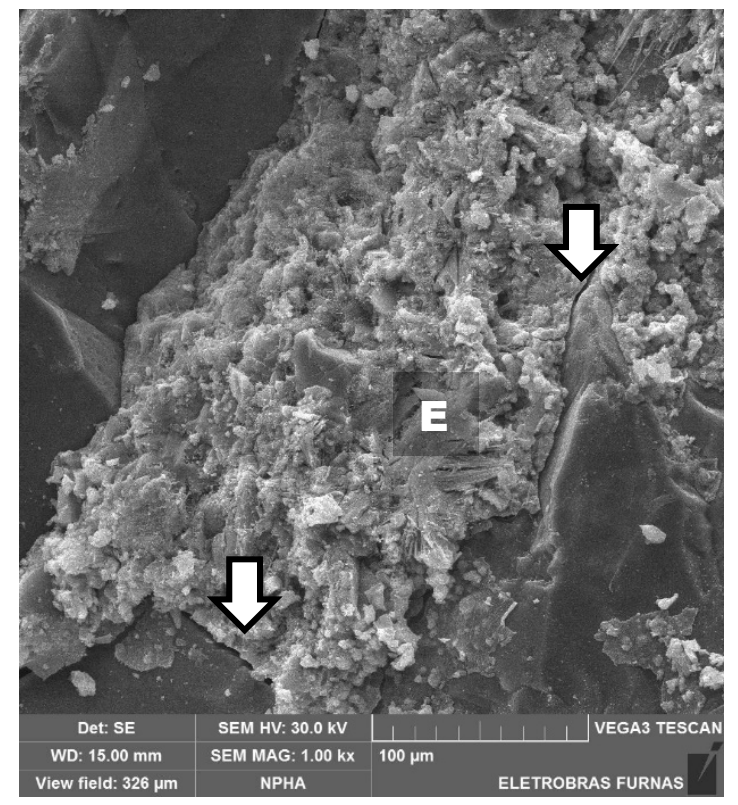

(b)

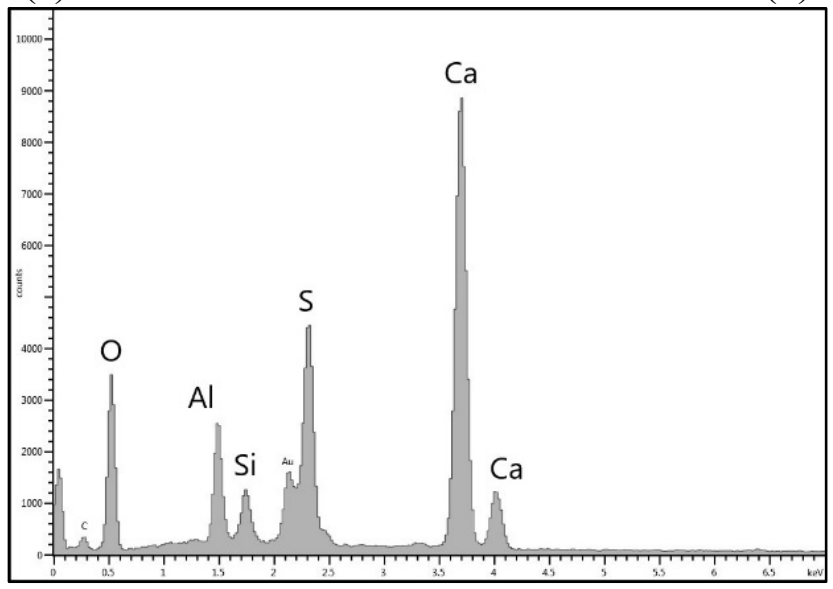

(c)

Figure 8. SEM micrography and EDS on day 180 of the assay for RHA concrete.

\section{CONCLUSIONS}

The behavior of concretes produced with RHA and induced to DEF have been evaluated in the present work and experimental data have been discussed with previous studies.

The thermal cycle adopted was able to induce DEF for both concretes (with and without RHA), according to microstructure features of concretes and also mechanical properties determined.

Compressive strength and modulus of elasticity were impaired due to the high expansion levels at 180 days $(0.23 \%$ for RHA and $0.30 \%$ for Ref.) and incidence of cracking.

This study has concluded that the RHA tested, and at $8 \%$, was not able to completely mitigate DEF consequences, considering the conditions assessed and the materials used in the experimental program. 


\section{AKNOWLEDGES}

The authors would like to acknowledge Faculdade Meridional (IMED) - Passo Fundo/RS Campus and ANEEL/FURNAS CENTRAIS ELÉTRICAS S.A. for the support.

This research was based upon a R\&D Project from ANEEL - National Agency, " Uso de bioconcretos e bio-mmfs de baixo impacto ambiental visando o aumento da eficiência energética de prédios públicos" - PD.0394-1719/2017, supported by Eletrobras Furnas with UFRJ cooperation.

\section{REFERENCES}

Amine, Y., Leklou, N., Amiri, O. (2017), Effect of supplementary cementitious materials (SCM) on delayed ettringite formation in heat-cured concretes. Energy Procedia. 139:565-570.

https://doi.org/10.1016/j.egypro.2017.11.254

Asamoto, S., Murano, K., Kurashige, I. (2017), Effect of carbonate ions on delayed ettringite formation. Construction and Building Materials. 147:221-226.

https://doi.org/10.1016/j.conbuildmat.2017.04.107

Associação Brasileira de Normas Técnicas. (2018). NBR 5739: Concreto - Ensaio de Compressão de Corpos de Prova Cilíndricos. Rio de Janeiro.

Associação Brasileira de Normas Técnicas. (2017). NBR 8522: Concreto - Determinação dos Módulos Estáticos de Elasticidade e de Deformação à Compressão. Rio de Janeiro.

Bauer, S., Cornell, B., Figurski, D., Alkali-silica reaction and delayed ettringite formation in concrete: A literature review. Report: Project performed in cooperation with the Texas Department of Transportation and the Federal Highway Administration. Center for Transportation Research at the University of Texas at Austin, 2006.

Bronholo, J. (2020), "Estudo do ataque individual e misto de DEF e RAA e de seus efeitos deletérios nas propriedades físico-químicas e mecânicas de concretos e argamassas de cimento portland Pozolânico e de alta resistência" Master Thesis, Instituto de Engenharia do Paraná, p. 216.

Das, S. K., Mishra, J., Singh, S. K. (2020), Characterization and utilization of rice husk ash (RHA) in fly ash - Blast furnace slag based geopolymer concrete for sustainable future. Materials Today: Proceedings. 30:1-12.

https://doi.org/10.1016/j.matpr.2020.02.870

Foreign Agricultural Service, United States Department of Agriculture. World Agricultural Production. 2019. Available in: https://www.fas.usda.gov/data/world-agricultural-production. Accessed on: may. 2021.

Fournier, B., Bérubé, M. (2020), Alkali-aggregate reaction in concrete: a review of basic concepts and engineering implications. Canadian Journal of Civil Engineering. 27:167-191.

https://doi.org/10.1139/199-072 
Gartner, E., Hirao, H. (2015), A review of alternative approaches to the reduction of CO2 emissions associated with the manufacture of the binder phase in concrete. Cement and Concrete Research. 78:126-142.

https://doi.org/10.1016/j.cemconres.2015.04.012

Giannini, E. R., Sanchez, L. F. M., Tuinukuafe, A. (2018), Characterization of concrete affected by delayed ettringite formation using the stiffness damage test. Construction and Building Materials. 162:253-264.

https://doi.org/10.1016/j.conbuildmat.2017.12.012

Givi, A. N., Rashid, S. A., Aziz, F. N. A. (2010), Contribution of rice husk ash to the properties of mortar and concrete: A review. Journal of American Science. 6:157-165.

Godart, B. (2017), Pathology, assessment and treatment of structures affected by delayed ettringite formation. Structural Engineering International. 27:362-369.

https://doi.org/10.2749/101686617X14881932436771

Hasparyk, N. P. (1999), "Investigação dos mecanismos de reação álcali-agregado - Efeito da cinza de casca de arroz e da sílica ativa”, Master Thesis, Universidade Federal de Goiás, p. 281.

Hasparyk, N. P., Kuperman, S. C. (2019), “Deterioração do concreto por reações expansivas”. In: XXXII - Seminário Nacional de Grandes Barragens - SNGB. - Comitê Brasileiro de Barragens - CBDB. Salvador (Brazil).

Hasparyk, N. P., Schovanz, D., Kuperman, S. (2020), “Método de ensaio para a avaliação do potencial de ocorrência da etringita tardia (DEF) em concreto”. Goiânia: Ed. Furnas.

IFSTTAR - Institut Francais des Sciences et Technologies des Transports, de l'Amenagement et des Reseaux. (2018). "Recommendations for preventing disorders due to Delayed Ettringite Formation”. Merne-la-Vallée. Technics and methods, GTI5-A, 70p. ISBN 978-2-85782-745-0.

Irga. Divisão de Assistência Técnica e Extensão Rural. “Boletim de resultados da lavoura”. 2021. Available in: https://irga.rs.gov.br/safras-2. Accessed on: may 2021.

LCPC - Laboratoire Central des Ponts et Chaussées (2009), "Guide technique - Recommendations for preventing disorders due to Delayed Ettringite Formation". Paris.

Leklou, N., Nguyen, V., Mounanga, P. (2016), The effect of the partial cement substitution with fly ash on delayed ettringite formation in heat-cured mortars. KSCE Journal of Civil Engineering, 21:1359-1366.

https://doi.org/10.1007/s12205-016-0778-9

Lopes, E. R., Medina, A. L., Ribeiro, A. S. (2017), Caracterização elementar da casca de arroz e suas cinzas por MIP OES após decomposição ácida com sistema de refluxo. Química Nova. 40: 1009-1017.

https://doi.org/10.21577/0100-4042.20170119 
Jeong, J., Ramézani, H., Leklou, N. (2017), Porous-micro-dilatation theory for random crystallization: Monte Carlo simulation for delayed ettringite formation. Acta Mechanica. 228(9):3223-3249.

Mehta, P. K., Monteiro, P. J. M. (2014), “Concreto: estrutura, propriedades e materiais”, 2. ed. Hasparyk, N.P. (Ed.). São Paulo: IBRACON, Brazil.

Melo, S. K. (2010), "Estudo da formação da etringita tardia em concreto por calor de hidratação do cimento”, Master Thesis, Universidade Federal de Goiás, p. 286.

Oliveira, S., Amantino, G. M., Hasparyk, N. P., Tiecher, F. (2020), “Avaliação do potencial da cinza de casca de arroz na mitigação da DEF” in: IBRACON (Eds.), $62^{\circ}$ Congresso Brasileiro do Concreto, Florianópolis: (Brazil), pp. 1-16.

Ramasamy, V. (2011), Compressive strength and durability properties of rice husk ash concrete. KSCE Journal of Civil Engineering. 16:93-102.

https://doi.org/10.1007/s12205-012-0779-2

Ramlochan, T., Zacarias, P., Thomas, M. D. A., Hooton, R. D. (2003), The effect of pozzolans and slag on the expansion of mortars cured at elevated temperature Part I: Expansive behavior. Cement and Concrete Research. 33:807-814.

https://doi.org/10.1016/S0008-8846(02)01066-9

Sanchez, L. F. M., Drimalas, T., Fournier, B. (2018), Comprehensive damage assessment in concrete affected by different internal swelling reaction (ISR) mechanisms. Cement and Concrete Research, 107:284-303.

https://doi.org/10.1016/j.cemconres.2018.02.017

Saraswathy, V., Song, H. (2006), Corrosion performance of rice husk ash blended concrete. Construction and Building Materials. 21:1779-1784.

https://doi.org/10.1016/j.conbuildmat.2006.05.037

Sensale, G. R. (2010), Effect of rice-husk ash on durability of cementitious materials. Cement \& Concrete Composites. 32:718-725.

https://doi.org/10.1016/j.cemconcomp.2010.07.008

Schovanz, D. (2019), "Estudo da formação da etringita tardia (def) em concretos com cimento portland pozolânico e de alta resistência”. Master Thesis, Faculdade IMED, p. 180.

Schovanz, D., Tiecher, F., Hasparyk, N. P., Kuperman, S. C. (2019), "Influência da formação da etringita tardia (DEF) na microestrutura e propriedades mecânicas do concreto" in: IBRACON (Ed.), 61 ${ }^{\circ}$ Congresso Brasileiro do Concreto, Fortaleza: (Brazil).

Schovanz, D., Tiecher, F., Hasparyk, N. P., Kuperman, S., Lermen, R. T. (2021), Evaluation of Delayed Ettringite Formation through Physical, Mechanical, and Microstructural Assays. ACI Materials Journal. 118:101-109. 
https://doi.org/10.14359/51728282

Seignol, J., Omikrine-Metalssi, O., Toutlemonde, F. (2012), "Recent advances in modeling DEFeffects” in: RILEM (Eds.), RILEM PRO-85, CONCRACK 3, Paris: (France), pp. 55-68.

Silva, A. S., Soares, D., Matos, L. (2010), Influence of mineral additions in the inhibition of delayed ettringite formation in cement based materials - A microstructural characterization. Materials Science Forum. 636-637:1272-1279.

https://doi.org/10.4028/www.scientific.net/MSF.636-637.1272

Taylor, H. F. W. (1997), “Cement Chemistry”, 2. Ed. Thomas Telford, London, England, p. 469.

Zerbino, R., Giaccio, G., Batic, O. R. (2012), Alkali-silica reaction in mortars and concretes incorporating natural rice husk ash. Construction And Building Materials. 36:796-806.

https://doi.org/10.1016/j.conbuildmat.2012.04.049 